\title{
Nep1 Protein from Fusarium oxysporum Enhances Biological Control of Opium Poppy by Pleospora papaveracea
}

\author{
Bryan A. Bailey, Patricia C. Apel-Birkhold, Olutayo O. Akingbe, Jessica L. Ryan, \\ Nichole R. O'Neill, and James D. Anderson
}

First, second, third, and fourth authors: Biocontrol of Plant Diseases Laboratory; fifth author: Soybean and Alfalfa Research Laboratory; and sixth author: Weed Science Laboratory, U.S. Department of Agriculture, Agricultural Research Service, Beltsville, MD 20705.

Accepted for publication 28 April 2000.

\begin{abstract}
Bailey, B. A., Apel-Birkhold, P. C., Akingbe, O. O., Ryan, J. L., O'Neill, N. R., and Anderson, J. A. 2000. Nep1 protein from Fusarium oxysporum enhances biological control of opium poppy by Pleospora papaveracea. Phytopathology 90:812-818.

The fungus Pleospora papaveracea and Nep1, a phytotoxic protein from Fusarium oxysporum, were evaluated for their biocontrol potential on opium poppy (Papaver somniferum). Four treatments consisting of a control, $P$. papaveracea conidia, Nep1 $(5 \mu \mathrm{g} / \mathrm{ml})$, and $P$. papaveracea conidia plus Nep1 $(5 \mu \mathrm{g} / \mathrm{ml})$ were used in detached-leaf and whole-plant

days when stored at $4^{\circ} \mathrm{C}$ or for 28 days at $20^{\circ} \mathrm{C}$. The presence of Nep1 did not affect conidia germination or appressoria formation. Nep1 was recovered from drops applied to opium poppy leaves in greenhouse and field studies $24 \mathrm{~h}$ after treatment. Opium poppy treated with the combination of Nep1 and P. papaveracea had higher necrosis ratings than the other treatments. There were changes in the intercellular protein profiles, determined by sodium dodecyl sulfate gel electrophoresis and silver staining, due to application of treatments; the most intense occurred in response to the combination of Nep1 and $P$. papaveracea. The combination of Nep1 and $P$. papaveracea enhanced the damage caused to opium poppy more than either component alone.
\end{abstract} studies. Conidia of $P$. papaveracea remained viable for 38 days when stored at 20 or $4^{\circ} \mathrm{C}$. Nep1 was stable in the presence of conidia for 38
Additional keywords: active oxygen, Silwet-L77, surfactant.
Biocontrol strategies $(2,14,21)$ involving the fungus Pleospora papaveracea are being developed as an alternative to chemical herbicides (15) for control of opium poppy (Papaver somniferum L.). Opium poppy is grown in many countries under diverse field conditions for illegal production of heroin $(8,18)$.

$P$. papaveracea is a loculoascomycetous fungus that overwinters in infested poppy stubble producing ascospores from pseudothecia in the spring $(12,20)$. Secondary inoculum consists of multicelled conidia that are produced in infested tissue (20). Initial efforts using conidial preparations of $P$. papaveracea for control of opium poppy in the field were ineffective at providing inundative biological control (7) of opium poppy (3). Once opium poppy plants grow out of the seedling stage, they are generally very susceptible to $P$. papaveracea and become severely infected as they begin to flower (25). If the initial damage caused to opium poppy by $P$. papaveracea could be increased, the potential usefulness of the biocontrol agent would be greatly enhanced.

Nep1 is a phytotoxic protein produced by the fungus Fusarium oxysporum $(1,4)$. Nep1 is produced and easily purified from culture filtrates of many isolates of $F$. oxysporum (4). Nep1 induces production of ethylene and causes extensive necrosis in many dicotyledonous plant species (1) including some noxious weeds (16). Nep1 can be applied as a foliar spray with the appropriate wetting agents, penetrate the leaf surface, and cause necrosis (16).

Corresponding author: B. A. Bailey; E-mail address: baileyb@ba.ars.usda.gov

The use of trade names or commercial products in this publication is solely for the purpose of providing specific information and does not imply recommendation or endorsement by the U.S. Department of Agriculture.

Publication no. P-2000-0530-02R

This article is in the public domain and not copyrightable. It may be freely reprinted with customary crediting of the source. The American Phytopathological Society, 2000.
The objectives of the research presented here were to determine whether Nep1 could be combined with $P$. papaveracea to provide enhanced control of opium poppy and to determine the stability of $P$. papaveracea and Nep1, individually and in combination.

\section{MATERIALS AND METHODS}

Nep1 purification. The Nep1 protein was purified from culture filtrates of $F$. oxysporum f. sp. erythroxyli and grown for 6 days in Czapek-Dox broth plus $1 \%$ casamino acids, as described by Bailey (1). The protein was maintained frozen at $-20^{\circ} \mathrm{C}$ in $20 \mathrm{mM}$ 2-morpholinoethanesulfonic acid (MES), and $300 \mathrm{mM} \mathrm{KCl}$ at $\mathrm{pH}$ 5.0. Protein concentrations were determined by Bradford analysis with the Bio-Rad (Hercules, CA) protein assay and bovine serum albumin (BSA) as a standard.

Fungal culture. $P$. papaveracea isolate Pf96 was isolated from opium poppies grown in the field in Beltsville, MD. Cultures were maintained in the dark at $25^{\circ} \mathrm{C}$ on $\mathrm{V} 8$ agar medium $(100 \mathrm{ml}$ of $\mathrm{V} 8$ juice, $2 \mathrm{~g}$ of $\mathrm{CaCO}_{3}$, and $15 \mathrm{~g}$ of agar per liter). Conidia were collected from 6- to 8-day-old V8 agar plates by surface washing with $2 \mathrm{ml}$ of $0.1 \%$ Tween 20. Conidia were washed in deionized water, pelleted by centrifugation $(10,000 \times g$ for $5 \mathrm{~min})$, and resuspended in deionized water and $0.001 \%$ Tween 20. Conidia were counted with a hemacytometer and diluted to the required concentrations.

Treatments. Various modifications of four standard treatments were used throughout the experiments. In greenhouse and field studies involving whole plants, treatments consisted of a control (wetting agent alone), $P$. papaveracea $\left(5 \times 10^{5}\right.$ conidia per $\left.\mathrm{ml}\right)$, Nep1 $(5 \mu \mathrm{g} / \mathrm{ml})$, and $P$. papaveracea $\left(5 \times 10^{5}\right.$ conidia per $\left.\mathrm{ml}\right)$ plus Nep1 $(5 \mu \mathrm{g} / \mathrm{ml})$. In studies using detached leaves, the concentration of $P$. papaveracea conidia was reduced to $1 \times 10^{4}$ conidia per $\mathrm{ml}$ to allow examination of individual conidia. The treatments, depending on the experiment, also contained $0.001 \%$ polyoxyethylene-sorbitan monolaurate (Tween 20), 0.5\% Tactic (Loveland 
Industries Inc., Greeley, CO), or 0.2\% 1,1,1,3,5,5,5-heptamethyltrisiloxanyl propyl-methoxy-poly (ethylene oxide) (Silwet-L77, OSI Specialties Inc., Endicott, NY) as wetting agents. Tween 20 $(0.001 \%, \mathrm{vol} / \mathrm{vol})$ was applied to detached leaves to minimize the influence of the wetting agent on both the fungus and protein, while aiding in adhering the suspension droplets to the leaf surface. Tactic was used in greenhouse experiments, and Silwet-L77 was used in field experiments. Tactic is a developmental formulation additive that serves as a wetting agent and carrier. Silwet-L77 $(0.2 \%, \mathrm{vol} / \mathrm{vol})$ is the most effective of the treatment additives for breaking surface tension and hydrostatic barriers (26).

Plant production. Opium poppy seed was obtained from a field in Colombia, South America, and the seed lot was designated Colombia. Opium poppy cv. White Cloud was produced from seed obtained from Thompson \& Morgan Ltd., Ipswich, England. Seeds of Colombia and White Cloud were planted in square $10.2-\mathrm{cm}$ pots in a controlled temperature $\left(12 \mathrm{~h}\right.$ of light at $21^{\circ} \mathrm{C}$ and $12 \mathrm{~h}$ of dark at $17^{\circ} \mathrm{C}$ ) growth chamber with a mixture of fluorescent and incandescent bulbs $\left(220 \mu \mathrm{mol} \mathrm{m} \mathrm{m}^{-2} \mathrm{~s}^{-1}\right)$. Six weeks after planting, opium poppy plants were used in detached-leaf experiments or as whole plants in greenhouse and field experiments.

Detached-leaf experiments. Experiments were carried out with detached opium poppy leaves to assess the stability of Nep1 in the presence of $P$. papaveracea and the influence of Nep1 on $P$. papaveracea spore viability. The four previously described treatments with $0.001 \%$ Tween 20 as a wetting agent were separated into 100- $\mu \mathrm{l}$ aliquots in microfuge tubes. Aliquots were stored at 4 or $20^{\circ} \mathrm{C}$. After storage times of $1,5,14,19,28$, and 38 days, $10-\mu \mathrm{l}$ drops ( 6 to 8 drops per leaf) of the four treatments were placed on detached leaves (three leaves per treatment) of White Cloud in petri plates containing sterile, moist filter paper to maintain humidity. At each time, $40 \mu \mathrm{l}$ of each formulation was frozen at $-20^{\circ} \mathrm{C}$ until used for sodium dodecyl sulfate (SDS) gel electrophoresis and western blotting. Except where otherwise indicated, the conidia were applied to the adaxial (top) surface of the leaf. Inoculated leaves were incubated at $29^{\circ} \mathrm{C}$ (light) for $6 \mathrm{~h}, 21^{\circ} \mathrm{C}$ (dark) for $10 \mathrm{~h}$, and $29^{\circ} \mathrm{C}$ (light) for $2 \mathrm{~h}$ prior to sectioning, unless otherwise indicated. After incubation, one leaf section from each of three leaves containing the conidial suspension was transferred to a glass slide. A drop of lactophenol (20\% phenol, 20\% lactic acid, $40 \%$ glycerol, and $20 \%$ water) containing $0.1 \%$ cotton blue was added to the leaf section (three leaf sections per treatment combination per time). The percentage of germination and number of appressoria formed were determined by counting germinated conidia and the number of appressoria with a light microscope at 400X magnification (Axioskop H/DK Stereo Microscope; Carl Zeiss, Thornwood, NY). Measurements were made at 5 ocular views per leaf section (3 leaf sections per treatment combination per time) for a total of 15 views per treatment combination per time. Each ocular view contained between 10 and 30 conidia. A conidium was considered to have germinated if a blue-staining germ tube was visible penetrating the spore wall. A minimum germ tube length of $0.93 \mu \mathrm{m}$ was observed. The experimental design was a three-way factorial, completely randomized design with storage time (0 to 38 days), storage temperature $\left(4\right.$ or $\left.20^{\circ} \mathrm{C}\right)$, and Nep1 concentration ( 0 or $5 \mu \mathrm{g} / \mathrm{ml}$ ) as factors. A replication consisted of the average of the five ocular views per leaf. There were three replications for each treatment combination, and the experiment was repeated twice.

Greenhouse experiments. Six weeks after planting, opium poppy plants were treated with the previously described treatments $\left(194 \mathrm{ml} / \mathrm{m}^{2}\right.$ of soil surface). The foliar spray was applied with a model 15 spraygun (Binks, Chicago) at $15 \mathrm{lb} / \mathrm{in}^{2}$. All treatments were applied between 1:30 and 3:00 p.m. Each treatment contained $0.5 \%$ Tactic as a wetting agent. Each plant was considered a replicate, and treatments were replicated four times. After treatment, plants were placed in a dew chamber $(18 \mathrm{~h}$ at $22^{\circ} \mathrm{C}$ ). After the dew period, plants were moved to a greenhouse bench. The experiment was repeated three times with both White Cloud and Colombia opium poppy. Disease severity was recorded weekly for 4 weeks after treatment. A visual rating scale of 0 to $100 \%$ whole-plant necrosis was used. The study used a completely randomized design with treatment as a factor. There were three replications for each treatment combination, and the experiment was repeated at least three times for White Cloud and Colombia.

Field experiments. Three experiments similar in design were carried out in Beltsville, MD. Six-week-old Colombia opium poppy plants were transplanted to the field on 8 and 27 April 1999. The plants were planted $19 \mathrm{~cm}$ apart. Each plant was considered a replicate, and treatments were replicated four times. Four weeks after the first transplanting, two experiments were initiated on consecutive days. The plants were treated with one of the four treatments previously mentioned at $129 \mathrm{ml} / \mathrm{m}^{2}$ of soil surface. The foliar spray was applied with a Binks Model 15 spraygun at $15 \mathrm{lb} / \mathrm{in}^{2}{ }^{2}$. All treatments were applied between 1:30 and 3:00 p.m. unless otherwise indicated. Each formulation contained $0.2 \%$ Silwet-L77 as a wetting agent. Two weeks after the second transplanting, a third experiment was initiated. Disease severity was recorded weekly for 4 weeks after treatment. A rating scale of 0 to $100 \%$ whole-plant necrosis was used. The experiment utilized a completely randomized design.

Recovery of Nep1 from the leaf surface. The four treatments, as previously described in detached-leaf experiments, were applied as $20-\mu \mathrm{l}$ drops ( $20 \mu \mathrm{g}$ of Nep1 per ml, 6 drops per leaf) on detached leaves of White Cloud in petri dishes containing sterile, moist filter paper or on leaves of Colombia in the field. Drops were placed on the abaxial or adaxial surfaces of leaves in the detached-leaf experiments. The drops placed on detached leaves remained in place and were recovered $24 \mathrm{~h}$ after application. In the case of field treatments, the drops evaporated, and 20- $\mu$ drops of gel-loading buffer were placed on the treated spot. The gelloading buffer was recovered after repeated mixing of the drop on the leaf surface with a $100-\mu l$ pipette. The samples were stored at $-20^{\circ} \mathrm{C}$ until used for SDS gel electrophoresis and western blotting.

Statistical analysis. The data were analyzed using the SAS general linear models procedure (version 6.04, SAS Institute Inc., Cary, NC). Mean comparisons were carried out according to LSD $(P \leq 0.05)$.

Isolation of intercellular fluids. Twenty-four hours after treatment of opium poppies, as previously described for greenhouse experiments, two leaves were removed from each plant. Leaves were dipped in $0.1 \%$ Silwet-L77 for $60 \mathrm{~s}$ and placed in

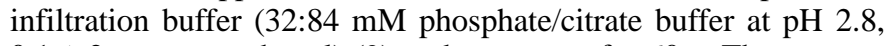
$0.1 \%$ 2-mercaptoethanol) (9) under vacuum for $60 \mathrm{~s}$. The vacuum was slowly released, and leaves were blotted dry with paper towels. Leaves were rolled up and placed in a 14-ml centrifuge tube with a bottomless $1.65-\mathrm{ml}$ microfuge tube placed in the bottom. The microfuge tube prevented the leaves from collapsing to the bottom of the centrifuge tube. The leaves were centrifuged at $3,000 \times g$ for $5 \mathrm{~min}$ The intercellular fluid that collected in the bottom of the tube was recovered and stored at $-20^{\circ} \mathrm{C}$ until used for SDS gel electrophoresis.

Western blots. Protein profiles of intercellular fluids, conidial or Nep1 suspensions, and infection site washes were determined by SDS polyacrylamide gel electrophoresis (SDS-PAGE) by the Tris-Tricine system (24) with a Bio-Rad Mini-Protean II gel apparatus. As standard protocol, equal volumes of protein samples were loaded without addition of 2-mercaptoethanol (1). Gels were silver-stained as described by Wray et al. (30). In some cases, proteins were transferred to nitrocellulose membrane by electroblotting with a Bio-Rad Mini Trans-Blot electrophoretic transfer cell. Transfer took $1 \mathrm{~h}$ at $100 \mathrm{~V}$ in $25 \mathrm{mM}$ Tris-HCl, $192 \mathrm{mM}$ glycine, and $20 \%$ methanol at $\mathrm{pH}$ 7.6. The nitrocellulose membrane was blocked for $1 \mathrm{~h}$ in $4 \%$ nonfat dry milk. The blots were incubated overnight in $25 \mathrm{ml}$ of $20 \mathrm{mM}$ Tris- $\mathrm{HCl}, 500 \mathrm{mM} \mathrm{NaCl}$, and 
$0.05 \%$ Tween 20 at $\mathrm{pH} 7.6$ (TST) plus antiserum to denatured Nep1. The blots were washed four times for 5 min each in $25 \mathrm{ml}$ of TST. The washed blots were incubated for $1 \mathrm{~h}$ with $25 \mathrm{ml}$ of TST plus $500 \mu \mathrm{l}$ of $4 \%$ nonfat dry milk and $10 \mu \mathrm{l}$ of goat anti-rabbit immunoglobulin (IgG) alkaline phosphatase conjugate. The blots were washed for $10 \mathrm{~min}$ in $25 \mathrm{ml}$ of $20 \mathrm{mM}$ Tris- $\mathrm{HCl}$, and $500 \mathrm{mM} \mathrm{NaCl}(\mathrm{pH}$ 7.6) buffer and washed two times for $10 \mathrm{~min}$ each in $100 \mathrm{mM}$ diethanolamine (pH 9.6) with $1 \mathrm{mM} \mathrm{MgCl}$. The blots were developed with 5-bromo-4-chloro-3-indolyl phosphate/ nitro blue tetrazolium (BCIP/NBT) tablets (Sigma Chemical Co., St. Louis) in distilled water.

\section{RESULTS}

Detached-leaf experiments. Conidia of $P$. papaveracea in $0.001 \%$ Tween 20 remained viable for up to 38 days when stored at both 20 and $4^{\circ} \mathrm{C}$ (Fig. 1). Germination was significantly altered (Table 1 ) by storage at $20^{\circ} \mathrm{C}$ compared with storage at $4^{\circ} \mathrm{C}$. Conidia germination was 99,87 , and $91 \%$ after storage at $20^{\circ} \mathrm{C}$ and 99,98 , and $93 \%$ after storage at $4^{\circ} \mathrm{C}$ for 0,20 , and 38 days, respectively. The presence of Nep1 had no effect on conidial germination. Production of appressoria was significantly affected by the interaction of storage temperature and time (Table 1). There were between 60 and 80 appressoria formed per 100 conidia when the treatments were stored at $20^{\circ} \mathrm{C}$ (Fig. 1). The primary effect of storage temperature was an increase in appressoria formation from 10 to $30 \%$ after storage at $4^{\circ} \mathrm{C}$ for 5 or more days compared with day 0 and storage at $20^{\circ} \mathrm{C}$ for 5 or more days (Fig. 1). There was frequently more than one appressorium formed per conidium. The presence of Nep1 had no effect on appressoria formation. The results were similar between the repeated experiments.

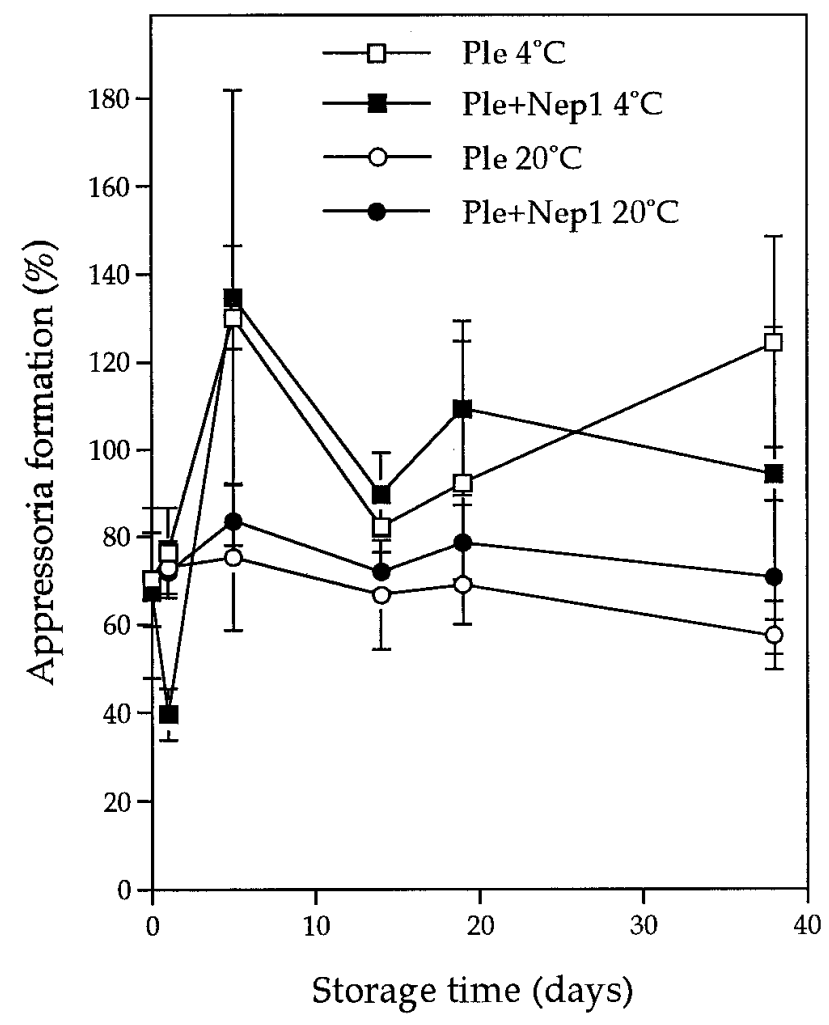

Fig. 1. Appressoria formation by Pleospora papaveracea $(\mathrm{Ple})$ conidia $(1 \times$ $10^{4} / \mathrm{ml}, 0.001 \%$ Tween 20 ) after storage for $1,5,14,19$, and 38 days at 4 or $20^{\circ} \mathrm{C}$ in the presence or absence of Nep1 protein $(5 \mu \mathrm{g} / \mathrm{ml})$. Eighteen hours after treating detached leaves of $\mathrm{cv}$. White Cloud opium poppy with $10-\mu 1$ drops of each treatment, the treated areas were sectioned and stained with lactophenol cotton blue, and the percentage of appressoria formed relative to the total number of spores counted was determined. A single spore often produced more than one appressorium, resulting in more than $100 \%$ appressoria formation in some cases.
Nep1 was stable in the presence of $P$. papaveracea for at least 38 days when stored at $4^{\circ} \mathrm{C}$ and for 28 days at $20^{\circ} \mathrm{C}$ (Fig. $2 \mathrm{~A}$ and B). Nep1 was almost completely removed from the treatments when stored for 38 days at $20^{\circ} \mathrm{C}$ (Fig. 2B). The loss of Nep1 occurred in both the presence and absence of $P$. papaveracea. Nep1 could be recovered from drops applied to opium poppy leaves in both detached-leaf (Fig. 3A) and field experiments (Fig. 3B) $24 \mathrm{~h}$ after treatment. Recovery was greatest in the detached-leaf experiments when the drops remained on the leaves.

Greenhouse experiments. There was a highly significant effect of treatment on the amount of necrosis caused on White Cloud $(P \leq 0.0001)$ and Colombia $(P \leq 0.0001)$ opium poppy in the greenhouse experiments (Fig. 4). The combination of Nep1 with $P$. papaveracea caused a greater increase in necrosis on both White Cloud (Fig. 5A) and Colombia (Fig. 5B) opium poppy than the other treatments. In the data from the two experiments presented (Fig. 5), the necrosis ratings for individual opium poppy plants treated with the combination of Nep1 and $P$. papaveracea ranged from 60 to $95 \% 7$ days after treatment. In data from these same experiments, opium poppy plants treated with the pathogen alone had necrosis ratings ranging from 7 to $50 \%$. The necrosis ratings for plants treated with Nep1 alone were between 1 and 5\%. Damage to plants caused by Nep1 was concentrated on the undersides and margins of leaves and on the small leaves in the center of the crown. Plants treated with Tactic alone had necrosis ratings of $1 \%$. The response to treatment with the combination of Nep1 and $P$. papaveracea was significantly greater than the individual treatments in all experiments. The levels of response to treatment with Nep1 or P. papaveracea alone varied between experiments.

Field experiments. When treatments were applied in the field, the combination of Nep1 and P. papaveracea always caused the most damage. The data from two field experiments with similar levels of response were combined for statistical analysis, and the data are presented. There was a highly significant effect of treatment on the amount of leaf necrosis $(P \leq 0.0018)$ on Colombia opium poppy. The Silwet-L77 control treatment (Fig. 6) was slightly phytotoxic (6.9\% on average). Silwet-L77 was used in field experiments because neither 0.5 nor $1.0 \%$ Tactic was effective at allowing Nep1 protein to penetrate and damage field-grown opium poppy plants (data not shown). While $0.2 \%$ Silwet-L77 alone damaged opium poppy plants, the addition of Nep1 $(5 \mu \mathrm{g} / \mathrm{ml})$ significantly increased foliar necrosis from 6.9 to $29.4 \%$ (Fig. 6). Similarly, the addition of $P$. papaveracea $\left(5 \times 10^{5}\right.$ conidia per $\left.\mathrm{ml}\right)$ alone increased foliar necrosis to $26.5 \%$ (Fig. 6). The combination of Nep1 and $P$. papaveracea increased the foliar necrosis to $55.0 \%$ (Fig. 6).

Intercellular proteins profiles. The various treatments induced major changes in the intercellular protein profiles as determined by SDS gel electrophoresis (Fig. 7). Treatment with Nep1 in $0.5 \%$ Tactic caused a decrease in protein with a relative molecular

TABLE 1. Effects of storage temperature $\left(4\right.$ and $\left.20^{\circ} \mathrm{C}\right)$ and storage time on the viability of Pleospora papaveracea conidia $\left(1 \times 10^{5}\right.$ conidia per $\left.\mathrm{ml}\right)$ in the presence and absence of the fungal protein Nep1 $(5 \mu \mathrm{g} / \mathrm{ml})$ as determined in detached-leaf assays

\begin{tabular}{lcc}
\hline & \multicolumn{2}{c}{$(P>F)^{\mathrm{a}}$} \\
\cline { 2 - 3 } Source & Germination $^{\mathrm{b}}$ & Appressoria \\
\hline Temp & $0.0186^{*}$ & $0.0001^{* * *}$ \\
Nep1 & 0.9359 & 0.6899 \\
Time & 0.0608 & $0.0015^{* *}$ \\
Temp $\times$ Nep1 & 0.2883 & 0.0928 \\
Temp $\times$ time & 0.0508 & $0.0058^{* *}$ \\
Nep1 $\times$ time & 0.4581 & 0.2405 \\
Temp $\times$ Nep1 $\times$ time & 0.4299 & 0.4080 \\
\hline a ${ }^{* * *}$, and ${ }^{* * *}$ indicate factors were significant at $P<0.05,0.01$, and 0.001, \\
respectively. \\
b Germination and formation of appressoria by conidia after 18 h on detached \\
opium poppy leaves were maintained on moist filter paper in petri dishes. \\
c Conidia were stored for up to 38 days.
\end{tabular}


weight of 20,000 and increases in other proteins with relative molecular weights of 25,000,31,000, and 40,000. P. papaveracea in $0.5 \%$ Tactic decreased the protein with a relative molecular weight of 20,000 and increased the protein with relative molecular

\section{A. 28 days}

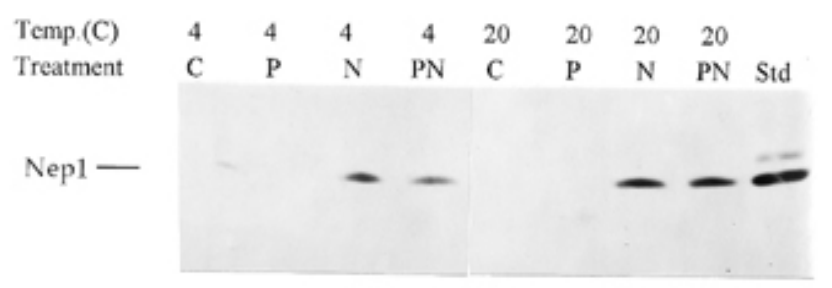

\section{B. 38 days}

$\begin{array}{llllllllll}\text { Temp.(C) } & 4 & 4 & 4 & 20 & 20 & 20 & 4 & 20 & \\ \text { Treatment } & \mathrm{P} & \mathrm{N} & \mathrm{PN} & \mathrm{P} & \mathrm{N} & \mathrm{PN} & \mathrm{C} & \mathrm{C} & \text { Std } \\ \text { Nepl- } & & & & & & & & & \end{array}$

Fig. 2. Stability of Nep1 in the presence and absence of Pleospora papaveracea conidia $\left(1 \times 10^{4} / \mathrm{ml}, 0.001 \%\right.$ Tween 20$)$ after storage $\mathbf{A}$, for 28 and $\mathbf{B}, 38$ days at 4 or $20^{\circ} \mathrm{C}$. $\mathrm{C}=$ control; $\mathrm{P}=P$. papaveracea conidia; $\mathrm{N}=\mathrm{Nep} 1$ protein $\mathrm{PN}=\mathrm{Nep} 1$ plus $P$. papaveracea conidia. The protein in samples of each treatment suspension $(10 \mu \mathrm{l})$ was separated by sodium dodecyl sulfate gel electrophoresis and transferred to nitrocellulose by western blotting. Nep1 was visualized by immunostaining with antiserum to denatured Nep1.
A. Greenhouse

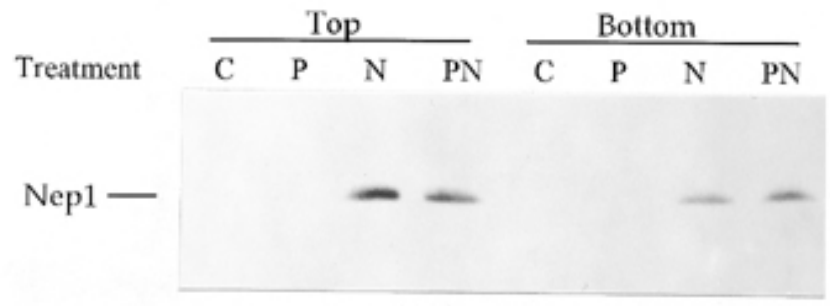

\section{B. Field}

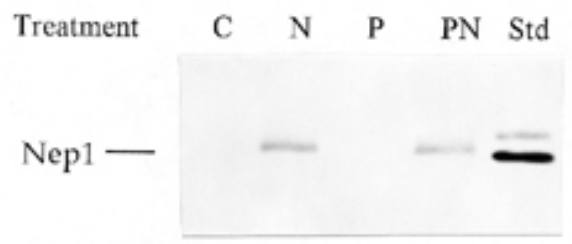

Fig. 3. Stability of Nep1 on opium poppy leaves $24 \mathrm{~h}$ after treatment with $20-\mu \mathrm{l}$ drops of control, Pleospora papaveracea $\left(5 \times 10^{5}\right.$ conidia per $\left.\mathrm{ml}\right)$, Nep1 protein $(5 \mu \mathrm{g} / \mathrm{ml})$, or $P$. papaveracea plus Nep1. Each treatment included $0.001 \%$ Tween 20 as a surfactant. $\mathrm{C}=$ control $; \mathrm{P}=P$. papaveracea conidia; $\mathrm{N}=\mathrm{Nep} 1 ; \mathrm{PN}=\mathrm{Nep} 1$ plus $P$. papaveracea conidia. A, Drops were applied to the top or bottom of detached leaves of cv. White Cloud opium poppy in petri dishes containing sterile, moist filter paper and incubated in the greenhouse. Drops placed on detached leaves remained in place and were recovered $24 \mathrm{~h}$ after application. B, Drops were applied to the tops of leaves of Colombia opium poppy in the field. The drops evaporated from the leaf surfaces in the field. Nep1 was recovered $24 \mathrm{~h}$ after treatment in a 20- $\mu$ l drop of gel-loading buffer that was placed on the treated spot. The protein recovered in $20-\mu \mathrm{l}$ samples of each treatment was separated by sodium dodecyl sulfate gel electrophoresis and transferred to nitrocellulose by western blotting. Nep1 was visualized by immunostaining with antiserum to denatured Nep1.

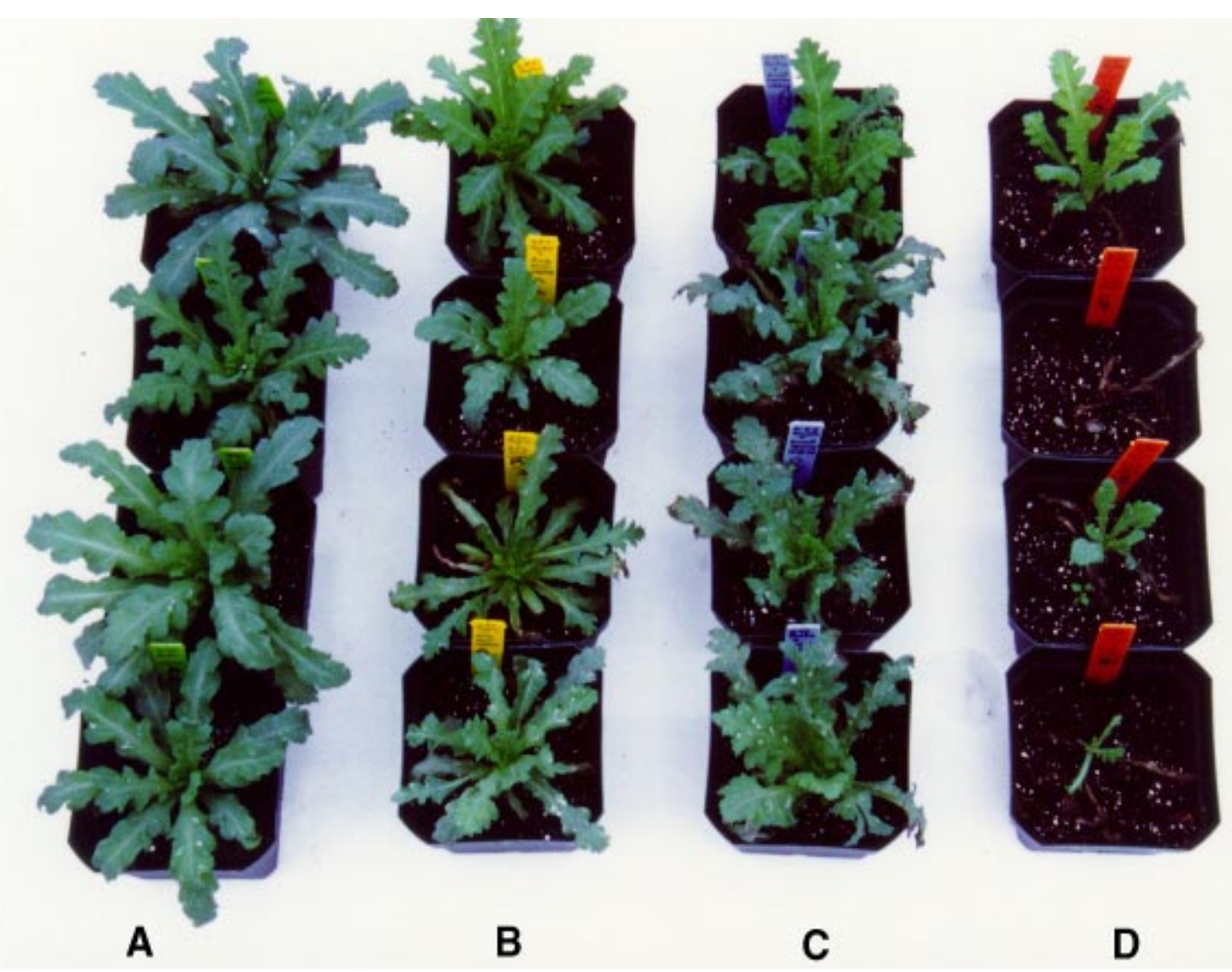

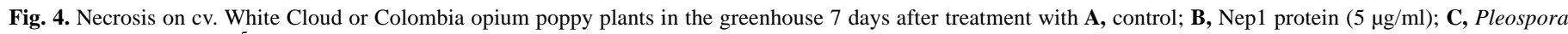

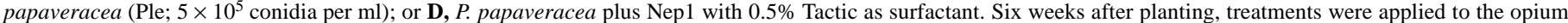
poppy plants as a foliar spray $\left(194 \mathrm{ml} / \mathrm{m}^{2}\right.$ of soil surface $)$. 
weights of $25,000,31,000,48,000$, and 51,000, but did not affect the protein with a molecular weight of 40,000 . The combination of Nep1 with $P$. papaveracea caused a decrease in the protein with a relative molecular weight of $20 \mathrm{kDa}$ and very strong increases in proteins with relative molecular weights of 25,000, 31,000, $40,000,48,000$, and 51,000.

\section{DISCUSSION}

Conidia of $P$. papaveracea remained infective when stored in $0.001 \%$ Tween 20 for up to 38 days at $20^{\circ} \mathrm{C}$. The most significant effect of storage was enhanced appressoria formation after storage in $0.001 \%$ Tween 20 at $4^{\circ} \mathrm{C}$. It is unclear what caused the enhanced appressoria formation. The $0.001 \%$ Tween 20 is a minimal storage solution, and it is possible conidia could be stored for longer periods of time in $0.001 \%$ Tween 20 or other storage solutions. The ability to store conidia for extended periods of time is a valuable characteristic for a biocontrol agent (11). A 38-day storage period is limited compared with some biocontrol agents and minimal compared with chemical herbicides. A 38-day storage period, however, should allow sufficient time for delivery of the inoculum to targeted fields.

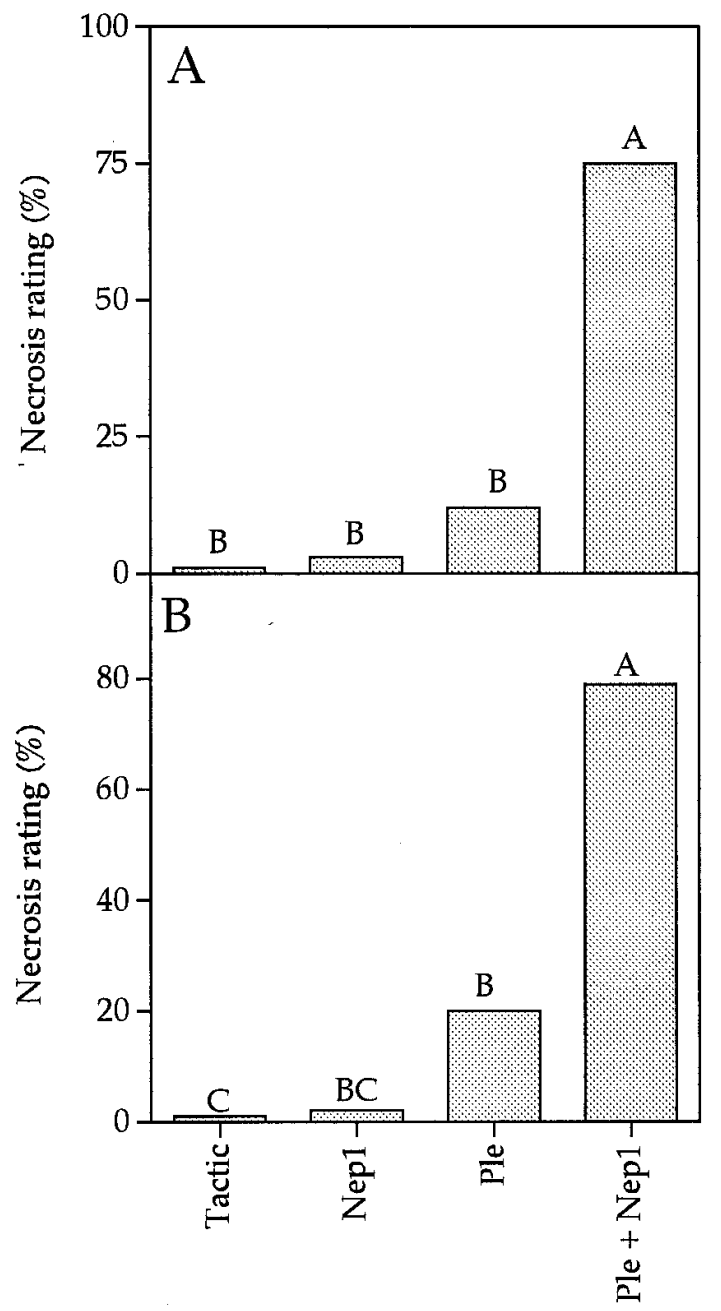

Treatment

Fig. 5. Necrosis on A, cv. White Cloud and $\mathbf{B}$, Colombia opium poppy plants in the greenhouse 7 days after treatment with control, Pleospora papaveracea (Ple; $5 \times 10^{5}$ conidia per $\left.\mathrm{ml}\right)$, Nep1 protein $(5 \mu \mathrm{g} / \mathrm{ml})$, or P. papaveracea plus Nep1. All treatments including the control contained $0.5 \%$ Tactic as a surfactant. Six weeks after planting, opium poppy plants were treated with a foliar spray $\left(194 \mathrm{ml} / \mathrm{m}^{2}\right.$ of soil surface) of one of the treatments. Data were recorded 7 days after treatment. Means with the same letter are not significantly different $(P=0.05)$ based on LSD.
The Nep1 protein was stable in the presence of $P$. papaveracea for at least 28 days when stored at $20^{\circ} \mathrm{C}$ but, by 38 days, was no longer detected in the stored suspensions regardless of the presence or absence of $P$. papaveracea. Nep1 was stable for as long as 38 days when stored at $4^{\circ} \mathrm{C}$. There were no special efforts made to maintain gnotobiotic conditions during storage. Nep1 was recovered from infected tissue in both the field and greenhouse experiments $24 \mathrm{~h}$ after treatment. Under these conditions there was extensive growth of $P$. papaveracea, plant cellular disruption, and the presence of unknown microorganisms, all of which were likely to produce proteinases.

The amount of damage caused by Nep1 varied. In some cases leaf necrosis occurred throughout the entire leaf thickness, but often necrosis was limited to the leaf margins, the abaxial epidermal layer, and the young leaves in the crown. Stomata, found only on the abaxial leaf surface of opium poppy, may serve as the primary means by which Nep1 enters the leaf. A second path of entry may be the hydathodes located on the leaf margins. Silwet-L77 $(0.2 \%)$ was used as a surfactant in the field experiments to enhance the damaging effect of Nep1 on opium poppy plants. Fieldgrown opium poppy plants were waxier and harder to wet than greenhouse-grown plants. Silwet-L77 has excellent wetting properties and carries spray solutions into the leaf mesophyll intercellular spaces through the stomata (26). The treatments pooled in the crown of the plants, which may explain the tendency of Nep1 to damage young leaves. The meristematic tissues remained viable presumably because Nep1 could not penetrate these tissues. The paths of entry into the leaf may have limited the damage Nep1 could cause alone.

The manner in which Nep1 damages plant tissue is being studied. Tissue necrosis is an end point in a complicated cascade of events that may include a specific interaction between the protein and plant cell components. Nep1 has demonstrated induced active oxygen production, ion channeling, altered respiration rates, and ultimately cell death in tobacco cell cultures (C. J. Baker, personal communication). These responses are commonly asso-ciated with plant hypersensitive resistance responses to infection $(5,17)$ and also with the response of plant cells to elicitors $(6,22)$. The

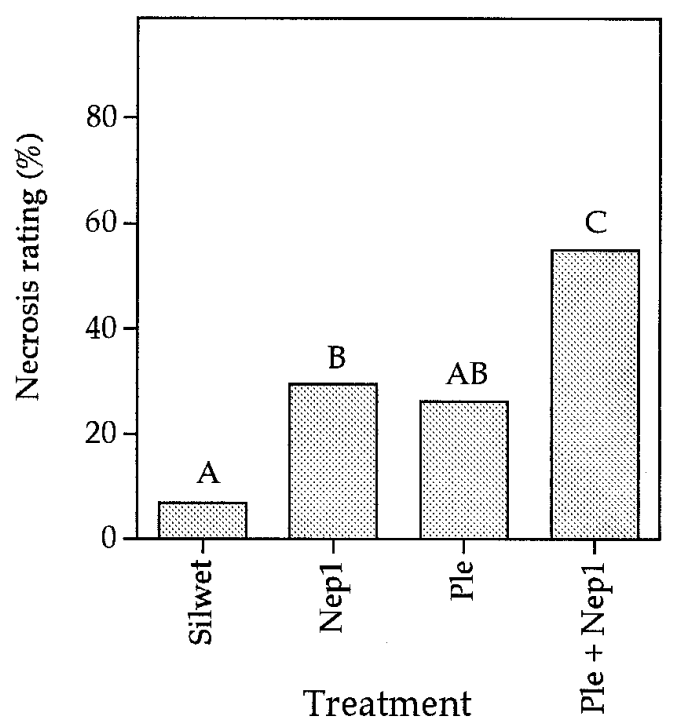

Fig. 6. Necrosis on Colombia opium poppy plants in the field 7 days after treatment with Silwet-L77 control, Pleospora papaveracea (Ple; $5 \times 10^{5}$ conidia per $\mathrm{ml}$ ), Nep1 protein $(5 \mu \mathrm{g} / \mathrm{ml})$, or $P$. papaveracea plus Nep1. All treatments including the control contained $0.2 \%$ Silwet-L77 as surfactant. Eight-week-old Colombia opium poppy plants were treated with a foliar spray $\left(129 \mathrm{ml} / \mathrm{m}^{2}\right.$ of soil surface $)$ of one of the treatments 2 weeks after transplanting to the field. Data were recorded 7 days after treatment. Means with the same letter are not significantly different $(P=0.05)$ based on LSD. 
bacterial protein harpin (6) and the class of fungal proteins grouped together as elicitins (22) cause many of these same responses in tobacco cell culture. In addition, harpin (29) and elicitins have induced resistance to disease in some plant species (22). The damage caused to opium poppy by Nep1 had no measurable negative effects on disease development by $P$. papaveracea, and in some cases, the effects were synergistic, producing much more damage than Nep1 or P. papaveracea alone.

$P$. papaveracea has considerable necrotrophic capability and is reported to produce toxins capable of damaging opium poppy (13). In addition, $P$. papaveracea is a good saprophyte, as evidenced by its ability to persist and reproduce in decaying poppy stubble (20). In several instances, combining weed biocontrol agents with phytotoxic compounds (chemical herbicides) has increased the efficacy of biocontrol agents (10). Necrotrophic pathogens have, in some cases, actually benefited from plant-produced active oxygen that damages plant tissue, which the pathogen can then colonize (28). Active oxygen production is a characteristic response to proteinaceous elicitors $(5,6,17,22)$, Nep1 (C. J. Baker, personal communication), and some chemical herbicides. It is probable that the exact outcome of treating plants with the combination of Nep1 and plant pathogens may depend on the plant-pathogen interaction being studied.

The quantity of several proteins in poppy leaf intercellular fluid extracts increased after treatment with Nep1 or $P$. papaveracea. The combination of Nep1 and $P$. papaveracea had the strongest effect on extractable intercellular proteins. At present these intercellular proteins have not been characterized, but opium poppies are likely to have many extracellular proteins in common with other plants, such as pathogenesis-related proteins (23). The treatment of opium poppy leaves with Nep1, P. papaveracea, or the combination of Nep1 and $P$. papaveracea caused a substantial reduction in intercellular proteins with a relative molecular weight of 20,000. An additional response attributed to active oxygen spe-

\section{Treatments}

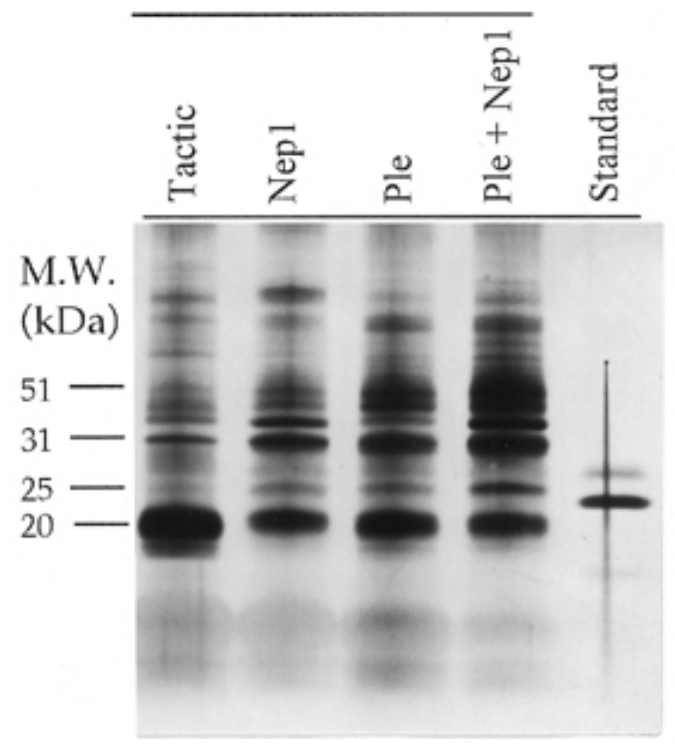

Fig. 7. Intercellular protein profiles from Colombia opium poppy leaves treated with Tactic control, Pleospora papaveracea (Ple; $5 \times 10^{5}$ conidia per ml), Nep1 protein $(5 \mu \mathrm{g} / \mathrm{ml})$, or $P$. papaveracea plus Nep1. All treatments including the control contained $0.5 \%$ Tactic as a surfactant. Six weeks after planting, treatments were applied as a foliar spray $\left(194 \mathrm{ml} / \mathrm{m}^{2}\right.$ of soil surface) to opium poppy plants in the greenhouse. After $24 \mathrm{~h}$, two leaves were removed from each plant, dipped in $0.1 \%$ Silwet-L77 for $60 \mathrm{~s}$, and placed in infiltration buffer under vacuum for $60 \mathrm{~s}$. The vacuum was slowly released, and the leaves were dried. Leaves were rolled up, placed in a 14-ml centrifuge tube, and centrifuged at 3,000 $\times g$ for $5 \mathrm{~min}$. The protein recovered from the intercellular fluid was separated by sodium dodecyl sulfate gel electrophoresis and silver-stained. cies during plant cell responses to pathogens and elicitors is the cross-linking of specific intercellular proteins to plant cell walls $(19,27)$. Proteins of 33 and 90 to $110 \mathrm{kDa}$ were preferentially removed from the extracellular fluid of soybean cells, while a $35-\mathrm{kDa}$ protein was preferentially removed from the extracellular fluid of bean cells following treatment with a fungal elicitor $(19,27)$. These proteins were characterized as a family of proline-rich proteins (33 and $35 \mathrm{kDa}$ ) and a family of glycoproteins (90 to $110 \mathrm{kDa}$ ) (19). It is hypothesized that these proteins serve to strengthen the cell wall and protect the cell from external stresses, such as pathogen invasion $(19,27)$. It is possible that the proteins with a relative molecular weight of 20,000 removed from opium poppy intercellular fluid by treatment with Nep1 or $P$. papaveracea have a similar function.

It remains unclear whether the response of plant cells to Nep1 should be considered a plant defense response to a fungal elicitor or simply necrosis in response to a fungal toxin. It is clear that Nep1 does not induce functional resistance in opium poppy to $P$. papaveracea under the conditions tested. The combination of $P$. papaveracea with Nep1 was consistently more damaging to opium poppy than either treatment alone. These observations raise the possibility that necrosis-inducing fungal proteins can be combined with necrotrophic weed pathogens to improve the efficacy of bioherbicide treatments.

\section{ACKNOWLEDGMENTS}

We thank M. Strem, D. Clark, and D. Reed for their dedication to this project including assistance with experiment setup and data collection.

\section{LITERATURE CITED}

1. Bailey, B. A. 1995. Purification of a protein from culture filtrates of Fusarium oxysporum that induces ethylene and necrosis in leaves of Erythroxylum coca. Phytopathology 85:1250-1255.

2. Bailey, B. A., Apel-Birkhold, P. C., Gracia-Garza, J., Hebbar, K. P., Nelson, A. J., Lumsden, R. D., and Elias, K. S. 1997. Strategies for biocontrol of narcotic plants. Pages 25-33 in: Proc. of the 1997 ONDCP Int. Technol. Symp. U.S. Gov. Printing, Washington, DC.

3. Bailey, B. A., Apel-Birkhold, P. C., O’Neill, N. R., Plaskowitz, J., Alavi, S., Jennings, J. C., and Anderson, J. D. Evaluation of infection processes and resulting disease caused by Dendryphion penicillatum and Pleospora papaveracea on Papaver somniferum. Phytopathology. In press.

4. Bailey, B. A., Jennings, J. C., and Anderson, J. D. 1997. The 24-kDa protein from Fusarium oxysporum f. sp. erythroxyli: Occurrence in related fungi and the effect of growth medium on its production. Can. J. Microbiol. 43:45-55.

5. Baker, C. J., O’Neill, N. R., Keppler, L. D., and Orlandi, E. W. 1991. Early responses during plant-bacterial interactions in tobacco cell-suspensions. Phytopathology 81:1505-1507.

6. Baker, C. J., Orlandi, E. W., and Mock, N. M. 1993. Harpin, an elicitor of the hypersensitive response in tobacco caused by Erwinia amylovora, elicits active oxygen production in suspension cells. Plant Physiol. 102:1341-1344.

7. Charudattan, R. 1988. Inundative control of weeds with indigenous fungal pathogens. Pages 86-110 in: Fungi in Biological Control Systems. M. N. Burge, ed. Manchester University Press, Manchester, England.

8. Choudhary, D. K., Kaul, B. L., Kak, S. N., Singh, C., and Ram, G. 1977. Cultivation and utilization of opium poppy in India: A review. Indian Drugs 15:2-8.

9. Christ, U., and Mosinger, E. 1989. Pathogenesis-related protein of tomato: I. Induction by Phytophthora infestans and other biotic and abiotic inducers and correlations with resistance. Physiol. Mol. Plant Pathol. 35:53-65.

10. Christy, A. L., Herbst, K. A., Kostka, S. J., Mullen, J. P., and Carlson, P. S. 1993. Synergizing weed biocontrol agents with chemical herbicides. Pages 87-100 in: ACS Symp. Ser. No. 524 American Chemical Society, Washington, DC.

11. Connick, W. J., Jr., Jackson, M. A., Williams, K. S., and Boyette, C. D. 1997. Stability of microsclerotial inoculum of Colletotrichum truncatum encapsulated in wheat flour-kaolin granules. World J. Microbiol. Biotechnol. 13:549-554

12. Farr, D. F., O’Neill, N. R., and van Berkum, P. B. 2000. Morphological and molecular studies on Dendryphion penicillatum and Pleospora 
papaveracea, pathogens of Papaver somniferum. Mycologia 92:145-153.

13. Grummer, G. 1952. Beitrage zur Eigenschaftsanalyse der Anfalligkeit von Papaver somniferum gegen Helminthosporium papaveris. Nachrichtenbl. Dtsch. Pflanzenschutzdienst 22:366-373.

14. Hebbar, K. P., O’Neill, N. R., Bailey, B. A., and Lumsden, R. D. 1997. Fermentation and formulation of Dendryphion penicillatum, a potential mycoherbicide of Papaver somniferum. (Abstr.) Phytopathology 87 (suppl.):S41.

15. Horowitz, M. 1980. Herbicidal treatments for the control of Papaver somniferum L. Bull. Narc. 1:33-43.

16. Jennings, J. C., Birkhold, P. C., Bailey, B. A., and Anderson, J. D. 2000. Induction of ethylene biosynthesis and necrosis in weed leaves by a Fusarium oxysporum protein. Weed Sci. 48:7-14.

17. Keppler, L. D., Baker, C. J., and Atkinson, M. M. 1989. Active oxygen production during a bacteria-induced hypersensitive reaction in tobacco suspension cells. Phytopathology 79:974-978.

18. Krikorian, A. D., and Ledbetter, M. C. 1975. Some observations on the cultivation of opium poppy (Papaver somniferum L.) for its latex. Bot. Rev. 42:30-103.

19. Lamb, C. J., Brisson, L., Bradley, D. J., and Kjellbom, P. 1993. Stimulusdependent oxidative cross-linking of a proline-rich plant cell wall protein: A novel, rapid defense response and control point in cellular maturation. Pages 250-256 in: Mechanisms of Plant Defense Responses. B. Fritig and M. Legrand, eds. Kluwer Academic Publishers, Dordrecht, the Netherlands.

20. Meffert, M. E. 1950. Ein beirtag zur biologie und morphologie der erreger der parasitaren blattdurre des mohns. Z. Parasitenkd. 14:442-498.

21. O’Neill, N. R., Jennings, J. C., Bailey, B. A., and Farr, D. F. Dendryphion penicillatum and Pleospora papaveracea, destructive seed-borne pathogens and potential mycoherbicides for Papaver somniferum. Phytopathology. In press.

22. Ricci, P., Panabieres, F., Bonnet, P., Maia, N., Ponchet, M., Devergne, J.-C., Marais, A., Cardin, L., Milat, M. L., and Blein, J. P. 1993. Proteinaceous elicitors of plant defense responses. Pages 121-135 in: Mechanisms of Plant Defense Responses. B. Fritig and M. Legrand, eds. Kluwer Academic Publishers, Dordrecht, the Netherlands.

23. Rushton, P. J., and Somssich, E. 1999. Transcriptional regulation of plant genes responsive to pathogens and elicitors. Pages 251-274 in: PlantMicrobe Interactions. G. Stacey and N. T. Keen, eds. The American Phytopathological Society, St. Paul, MN.

24. Schagger, H., and Jagow, G. 1987. Tricine-sodium dodecyl sulfatepolyacrylamide gel electrophoresis for the separation of proteins in the range from 1 to 100-kDa. Anal. Biochem. 166:368-379.

25. Schmitt, C. G., and Lipscomb, B. 1975. Pathogens of selected members of the Papaveraceae: An annotated bibliography. Page 185 in: Agricultural Research Service, U.S. Department of Agriculture, Beltsville, MD.

26. Stevens, P. J. G. 1993. Organosilicone surfactants as adjuvants for agrochemicals. Pestic. Sci. 38:103-122.

27. Tenhaken, R., Levine, A., Brisson, L. F., Dixon, R. A., and Lamb, C. 1995. Function of the oxidative burst in hypersensitive disease resistance. Proc. Natl. Acad. Sci. 92:4158-4163.

28. Tiedemannm, A. V. 1997. Evidence for a primary role of active oxygen species in induction of host cell death during infection of bean leaves with Botrytis cinerea. Physiol. Mol. Plant Pathol. 50:151-166.

29. Wei, Z.-M., and Beer, S. V. 1996. Harpin from Erwinia amylovora induces plant resistance. Acta Hortic. 411:223-225.

30. Wray, W., Boulikas, T., Wray, V. P., and Hancock, R. 1981. Silver staining of proteins in polyacrylamide gels. Anal. Biochem. 118:197-203. 